Article

\title{
How Heterogeneous Are the Determinants of Total Factor Productivity in Manufacturing Sectors? Panel-Data Evidence from Vietnam
}

\author{
Quang-Thanh Ngo ${ }^{1,2, * \mathbb{C}}$, Quang-Van Tran ${ }^{1,2, * \mathbb{D}}$, Tien-Dung Nguyen ${ }^{2,3}$ \\ and Trung-Thanh Nguyen 4,5 \\ 1 Center for Economic and Financial Research (CEFR), University of Economics and Law (UEL), \\ Ho Chi Minh City 71309, Vietnam \\ 2 University of Economics and Law (UEL), Vietnam National University Ho Chi Minh City (VNU-HCM), \\ Ho Chi Minh City 71309, Vietnam; ntdung@uel.edu.vn \\ 3 Board of Rectors, University of Economics and Law (UEL), Ho Chi Minh City 71309, Vietnam \\ 4 School of Economics and Management, Leibniz University Hannover, 30167 Hannover, Germany; \\ thanh.nguyen@iuw.uni-hannover.de or trungthanh.nguyen@duke.edu \\ 5 Trinity College of Arts and Sciences, Duke University, Durham, NC 27708, USA \\ * Correspondence: thanhnq@uel.edu.vn (Q.-T.N.); vantq@uel.edu.vn (Q.-V.T.)
}

Received: 27 April 2020; Accepted: 1 July 2020; Published: 6 July 2020

\begin{abstract}
One of the remaining challenges in explaining differences in total factor productivity is heterogeneity between sectors and within a specific sector in terms of labor and capital. This paper employs the generalized method of moments (GMM) to identify factors that affect total factor productivity across 21 manufacturing sectors and to clarify the heterogeneous determinants of total factor productivity within manufacturing sectors for the period 2010-2015. Our estimations show that large firms have significantly greater total factor productivity levels than small firms in some fragmentations of firms in terms of both labor and total capital and in some manufacturing sectors. It is suggested that firm characteristics should be considered by the government in establishing relevant policies for enhancing firm productivity.
\end{abstract}

Keywords: total factor productivity; panel causality; heterogeneity; manufacturing sector; Vietnam

JEL Classification: L25; O33; L60; C33

\section{Introduction}

Given the crucial role of total factor productivity (TFP) in economic growth and development, its determinants have been examined intensively in the relevant literature using a vast number of approaches. These include, for example, the "vintage effect" (Kendrick 1961; Hulten 1992; Hulten and Wykoff 1980; Harper 2007), the learning-by-doing effect (Jovanovic 1982; Pakes and Ericson 1998), resource-based theories (Penrose 1959; Wernerfelt 1984; Barney 2000, 2001), and a "neo-Schumpeterian" growth approach (Aghion and Howitt 2006). As a consequence, the literature on TFP determinants faces the problems of the "open-endedness" of alternative theories that can be applied and provides controversial results in empirical research (Brock and Durlauf 2001). This is because firms within and among sectors are not homogenous in terms of their size. Different levels of labor and capital use lead to different TFP levels. Therefore, taking into account the "within" and "between" heterogeneities in examining TFP is needed. In addition, many of these previous studies focused on the determinants of TFP in developed countries, as detailed panel data at the firm and sector levels are not available in many developing or emerging economies. 
This article is aimed at filling in this gap in the literature. Our analysis is based on panel data from the Vietnam Annual Enterprise Survey in 2010-2015. The data have been collected for years using the same sampling method and questionnaire. We focus on the manufacturing sectors, as they have been the main engine for economic growth in Vietnam during the last several years. We construct a production dataset that allows us to estimate TFP levels. Then, key internal TFP determinants are examined. Our estimations, in general, show that large firms have significantly greater TFP levels than small firms in some fragmentations of firms in terms of both labor and total capital and in some manufacturing sectors.

The paper contributes to the literature in several ways. First, our work extends the current literature (Castellani and Giovannetti 2010; Kreuser and Newman 2018; Kim 2018; Ngo and Tran 2020; Ngo and Nguyen 2019; Giang et al. 2019) by accounting for heterogeneity in examining the determinants of TFP at the firm level in a dynamically emerging economy. Second, we examine the TFP determinants in detail by exploring the issues at the levels of 21 manufacturing sectors, and not at level of the aggregated industry. Third, our estimation model is explored using a generalized method of moments (GMM) system estimator, which takes into account the possible endogeneity of some regressors. Fourth, our paper contributes to the empirical results relating to the endogenous growth theory as proposed by Evans (1998), especially in terms of manufacturing sectors within a specific country.

The remaining part of the article is structured as follows. Section 2 reviews the theoretical considerations and empirical evidence. Section 3 describes the data and methods employed in our study. Section 4 discusses the findings. Section 5 concludes the study.

\section{Literature Review}

A review of the literature on the determinants of enterprise productivity has been provided by Syverson (2011). In his paper, Syverson (2011) pointed out several factors relating to managerial practice/talent (Bloom and Reenen 2007, 2010), higher qualified labor and capital inputs (Ilmakunnas et al. 2004; Sakellaris and Wilson 2004; Van Biesebroeck 2003), information technology and R\&D (see for example Jorgenson et al. 2005, 2008; Oliner et al. 2007; Aw et al. 2008), learning-by-doing (Thornton and Thompson 2001), product innovation (Bartel et al. 2007; Bernard et al. 2010), and firm structure decisions (Bloom and Reenen 2010; Forbes and Lederman 2010). External drivers of productivity differences are also listed such as productivity spillovers (Martin et al. 2011), horizontal linkages (Nichter and Goldmark 2009), competition (Foster et al. 2008; Ali and Peerlings 2011), deregulation or proper regulation (Bridgman et al. 2009; Fabrizio et al. 2007; Brown et al. 2006), flexible input markets (Maksimovic and Phillips 2001; Hsieh and Klenow 2009; Bartelsman et al. 2009).

Since the work of Syverson (2011), several empirical studies have explored further potential determinants and in many directions (see, for example, Kreuser and Newman 2018; Kim 2018; Botrić et al. 2017; Satpathy et al. 2017; Venturini 2015; İmrohoroğlu and Tüzel 2014; Mohnen and Hall 2013). Kreuser and Newman (2018), using a firm-level sample of the South African manufacturing sector, found that there is heterogeneity of growth across subsectors. The authors also found a positive relationship between firm size and productivity level. Kim (2018) investigated firm heterogeneity in productivity sources across technology sectors for Japanese manufacturers. In this regard, large firms were found to be more productive. Besides, firm heterogeneity in productivity varied considerably across the technology sectors. Satpathy et al. (2017), using a sample of 616 Indian manufacturing companies from 1998-1999 to 2012-2013, found that the size of firms is important for productivity across the sub-industries. Venturini (2015) studied the role of technology spillovers in the productivity growth of OECD countries and found that both forms of technologically advanced capital (Information and communications technology (ICT) and R\&D) influence total factor productivity (TFP) over the long run. İmrohoroğlu and Tüzel (2014), exploring publicly traded firms in the United States between 1963 and 2009, showed that productivity is strongly related to several firm characteristics, such as size, the book-to-market ratio, investment, and hiring rate. Mohnen and Hall (2013) considered four types 
of innovations, namely: product, process, organizational, and marketing innovations in explaining productivity. The authors concluded that, given the imperfect measurement of innovation and the simultaneity of different types of innovation, it is difficult to isolate the individual effect of each. However, the authors found that some complementary seems to exist between them.

While we expect these determinants to be potentially relevant in the case of enterprises in developing countries, an emerging trend to consider is the heterogeneity of firms as indicated in Dhawan (2001), Castellani and Giovannetti (2010), Cao et al. (2017), Kreuser and Newman (2018), Kim (2018), and Ngo and Tran (2020). The heterogeneity of firms is said to be important in the sense that it composes the firms' characteristics (Kim 2018; Lu et al. 2017), and this affects the firm's productivity. Heterogeneity can be observed in terms of labor, capital between the large firms and the small ones, and in terms of efficiency between efficient firms and inefficient ones (Jovanovic 1982), and terms of investment decision (Head and Ries 2003). Firms are also heterogeneous in terms of the quality of managers and workers (Bloom and Reenen 2010), in terms of the level of international integration (Melitz 2003) and diversification of trading activities as well (Castellani and Giovannetti 2010). Last but not least, by investing in innovation activities, firms are differentiated in terms of technological level and learning (Castellani et al. 2010; Constantini and Melitz 2008; Goedhuys 2007). In this context, the implications from the heterogeneity of firms are taken into account when examining the determinants of productivity. In other words, determinants of productivity now need to be screened through the lens of firm heterogeneity in terms of labor and capital levels. From the above theoretical considerations, we examine the determinants of productivity of Vietnamese enterprises related to traditional factors, such as firm size, firms' ages, labor quality, and capital stock, which are examined in the context of firm heterogeneity.

\section{Data and Methods}

\subsection{Data}

We used panel data from the Vietnam Annual Enterprise Survey (VAES) in 2010-2015. This annual survey is managed by the Vietnamese General Statistical Office (GSO) and collects firms' information, such as labor and wages, assets and liabilities, and business performances.

All business entities (enterprises having a business account, and established under the regulations of the State Enterprise Law, Cooperative Law, Enterprise Law, and Foreign Investment Law) in the manufacturing sectors are surveyed. As each firm was assigned a tax code, we used this information to merge annual data to establish a panel dataset. We followed the sector and subsector classification as in Ngo and Tran (2020), Ngo and Nguyen (2019), and United Nations Statistical Division (2008). We kept only firms that have not changed their manufacturing sectors during the period 2010-2015, and firms with positive values of (1) value-added (VA), (2) intermediate materials, and (3) equity. We then eliminated outliers and anomalies by controlling for outliers on value-added, costs of materials, and total assets. Finally, we eliminated related sectors with a number of observations of less than 200 in total. Finally, we obtained the final dataset by dropping missing years. Several studies that used this dataset can be listed, such as Newman et al. (2015), Ngo and Nguyen (2019), Ngo and Tran (2020), and Tran et al. (2019).

\subsection{TFP Estimation}

We prefer the methodology developed by Ackerberg et al. (2006) (Ackerberg, Ackerberg, Dan, Kevin Caves, and Garth Frazer (AFC)), which is an extension of the technique by Levinsohn and Petrin (2003) for estimating TFP. The AFC procedure solves the problem of endogeneity, which may come from a part of the TFP affected by changes in the factor input decisions, and possible collinearity that exists between labor and proxy variables for the instruments. In addition, the paper employs the AFC procedure with the value-added method. Further, we use intermediate raw material as a proxy variable to ward off the bias problem as mentioned by Ackerberg et al. (2006). 


\subsection{Model Specification}

In the current study, our empirical model of the key determinants of TFP follows the framework by Evans (1998), Bernard and Jensen (1999), Clerides et al. (1998), Kreuser and Newman (2018), Kim (2018), and Giang et al. (2019).

Size: Several studies have found that firm size has a positive relationship with TFP thanks to the accumulation of knowledge of larger companies (the learning-by-doing effects; see: Van Biesebroeck (2005), İmrohoroğlu and Tüzel (2014), Malerba (1992), Lee and Tang (2001), and Jovanovic and Nyarko (1996)). On the other hand, studies by Williamson (1967), Tornatzky and Fleischer (1990), and Kim (2018) have concluded that small firms have higher productivity or efficiency due to their lean organizational structure. The size of a firm is usually calculated as the logarithm of total workers of the firm (Giang et al. 2019; Giang et al. 2018; Kreuser and Newman 2018).

An "age" variable is usually included to measure whether younger plants produce with greater efficiency and better technology than older plants (a vintage capital effect); or if through learning-by-doing productivity increases as the plant ages (Jovanovic and Nyarko 1996).

Furthermore, the measure of the capital stock used (Harris and Drinkwater 2000; Söderbom and Teal 2004) should, in theory, be adjusted to take account of vintage effects, which means the deterioration of used capital, and because new capital embodies the latest technology (leading to obsolescence in older vintages).

Isaksson (2007), in his extensive review on TFP determinants, argued that an increase in the quality of labor enhances absorptive capacity and thus technology transfer. The average wage level is used to capture the effect of labor quality (Castellacci 2007; Jung and Lee 2010; Kim 2018).

Kreuser and Newman (2018) also included value-added as an explanatory variable in the model of TFP determinants. We adjust value-added by the number of workers to minimize the problem of firms' heterogeneity in terms of labor size.

The empirical model of the determinants of TFP has the following form:

$$
\operatorname{TFP}_{i t}=\alpha+\delta X_{i t-1}+\phi T F P_{i t-1}+\sum_{j} \delta \phi_{j} \operatorname{Time}_{j}+\varepsilon_{i t}
$$

where $X$ is a vector of firm characteristics and TFP is the total factor productivity. $t$ and $i$ denote year and firm, respectively, in the model. The firm-level characteristics include capital stock (fixed capital), labor (size of employment), human capital (wage level), and firm age (years of operation). Besides, we include the total factor productivity of the previous year, mainly to deal with the possible endogeneity problem (Kim et al. 2009; Giang et al. 2018). We estimated Equation (1) for 21 manufacturing sectors separately.

The endogeneity problem may exist in estimating determinants of TFP. Value-added per worker can be endogenous, in addition to the total factor productivity of the previous year. To obtain consistent and unbiased estimates of regression coefficients, we adopted the dynamic panel generalized method of moments (GMM) estimation approach (Blundell and Bond 1998; Arellano and Bond 1991). This estimator transforms the regression variables by first differencing and removes the time-invariant characteristics (firm-level fixed effects). In practice, we allow control variables including the variables of capital-labor ratio and the number of workers to be predetermined, and use their lagged values as exogenous instruments in the GMM estimation. Other control variables, such as a firm's age and dummies for years, are treated as strict exogenous variables. The correct application strictly relies on the assumption of autocorrelation (Roodman 2009), which is largely taken care of with the lagged dependent variables as predictors. We also care about the assumptions on the over-identification and erogeneity of instruments to produce valid estimates. 


\section{Empirical Results}

\subsection{TFP Estimation Results}

Table 1 presents sample means and standard deviations of variables in the Cobb-Douglas production function model.

Table 1. Summary statistics for variables in Cobb-Douglas production function estimation.

\begin{tabular}{|c|c|c|c|c|c|c|c|c|c|}
\hline \multirow{2}{*}{ Sector } & \multirow{2}{*}{$\begin{array}{c}\text { Number of } \\
\text { Observations }\end{array}$} & \multicolumn{2}{|c|}{ Value-Added (ln) } & \multicolumn{2}{|c|}{ Fixed Capital (ln) } & \multicolumn{2}{|c|}{ Labor (ln) } & \multicolumn{2}{|c|}{$\begin{array}{l}\text { Raw Material } \\
\text { Expenses (ln) }\end{array}$} \\
\hline & & Mean & $\begin{array}{l}\text { Standard } \\
\text { Deviation }\end{array}$ & Mean & $\begin{array}{l}\text { Standard } \\
\text { Deviation }\end{array}$ & Mean & $\begin{array}{l}\text { Standard } \\
\text { Deviation }\end{array}$ & Mean & $\begin{array}{l}\text { Standard } \\
\text { Deviation }\end{array}$ \\
\hline 11: Beverages & 558 & 14.857 & 2.260 & 11.291 & 1.949 & 4.775 & 1.070 & 15.551 & 2.169 \\
\hline 13: Textiles & 2322 & 13.880 & 1.763 & 10.512 & 1.768 & 4.726 & 1.188 & 15.357 & 1.829 \\
\hline 14: Wearing apparel & 5208 & 14.755 & 1.622 & 10.261 & 1.481 & 5.896 & 1.327 & 15.341 & 1.622 \\
\hline 15: Leather and related products & 1746 & 15.359 & 1.770 & 10.910 & 1.808 & 6.427 & 1.616 & 16.069 & 1.790 \\
\hline $\begin{array}{l}\text { 18: Printing and reproduction of } \\
\text { recorded media }\end{array}$ & 1122 & 13.368 & 1.426 & 9.730 & 1.466 & 4.094 & 0.976 & 14.561 & 1.429 \\
\hline 20: Chemicals and chemical products & 2136 & 14.234 & 1.710 & 11.134 & 1.575 & 4.268 & 1.118 & 15.884 & 1.826 \\
\hline 21: Pharmaceuticals, medicinal chemicals & 618 & 15.017 & 1.561 & 11.707 & 1.351 & 5.140 & 1.051 & 16.046 & 1.533 \\
\hline 22: Rubber and plastics products & 3258 & 14.213 & 1.575 & 10.999 & 1.392 & 4.728 & 1.149 & 15.784 & 1.542 \\
\hline 23: Other non-metallic mineral products & 4332 & 13.799 & 1.684 & 10.583 & 1.664 & 4.710 & 1.116 & 14.887 & 1.829 \\
\hline 24: Basic metals & 714 & 14.008 & 1.865 & 11.386 & 1.778 & 4.456 & 1.215 & 16.377 & 1.970 \\
\hline $\begin{array}{l}\text { 28: Not-yet-classified machinery } \\
\text { and equipment }\end{array}$ & 942 & 13.478 & 1.697 & 10.557 & 1.558 & 4.241 & 1.187 & 14.907 & 1.566 \\
\hline $\begin{array}{l}\text { 29: Motor vehicles, trailers } \\
\text { and semi-trailers }\end{array}$ & 522 & 15.176 & 1.757 & 11.946 & 1.512 & 5.393 & 1.244 & 16.575 & 1.802 \\
\hline 30: Other transport equipment & 654 & 14.759 & 2.071 & 11.645 & 1.803 & 5.219 & 1.390 & 16.165 & 2.025 \\
\hline 31: Furniture & 2856 & 14.213 & 1.539 & 10.660 & 1.427 & 5.214 & 1.253 & 15.566 & 1.557 \\
\hline 34: Other manufacturing & 1080 & 14.209 & 1.688 & 10.550 & 1.564 & 5.133 & 1.323 & 15.203 & 1.704 \\
\hline
\end{tabular}

Source: authors' calculation from the Vietnam Annual Enterprise Survey (VAES) 2010-2015.

We estimated the Cobb-Douglas model in Section 3.2 for the 21 sectors. The results in Table 2 indicate that employees (in the natural logarithm) and capital (in the natural logarithm) are significant at the 1 percent level in most sectors.

Table 2. Estimation results of Cobb-Douglas production function using Ackerberg-Caves-Frazer estimator, 2010-2015.

\begin{tabular}{cccccccc}
\hline VARIABLES & Sector 10 & Sector 11 & Sector 13 & Sector 14 & Sector 15 & Sector 16 & Sector 17 \\
\hline Dependent variable: value-added (logarithm) & & & & & & \\
\hline Capital (ln) & $0.517^{* * *}$ & $0.800^{* * *}$ & $0.473^{* * *}$ & 0.0341 & $0.139^{* * *}$ & $0.389^{* * *}$ & $0.326^{* * *}$ \\
& $(0.0513)$ & $(0.145)$ & $(0.0192)$ & $(0.0227)$ & $(0.0362)$ & $(0.0349)$ & $(0.0493)$ \\
Labor $(\mathrm{ln})$ & $0.712^{* * *}$ & $0.605^{*}$ & $0.755^{* * *}$ & $1.105^{* * *}$ & $0.931^{* * *}$ & $0.901^{* * *}$ & $1.041^{* * *}$ \\
& $(0.0724)$ & $(0.314)$ & $(0.0332)$ & $(0.0378)$ & $(0.0385)$ & $(0.0862)$ & $(0.109)$ \\
Observations & 4865 & 485 & 2010 & 4445 & 1525 & 1820 & 1770 \\
Wald test statistic of constant returns to scale & 85.48 & 5.162 & 152.7 & 50.19 & 24.73 & 23.71 & 30.35 \\
Sargan-Hansen test statistic & $4.19 \times 10^{-9}$ & $3.87 \times 10^{-8}$ & $6.84 \times 10^{-9}$ & $3.03 \times 10^{-8}$ & $2.89 \times 10^{-8}$ & $1.45 \times 10^{-9}$ & $1.78 \times 10^{-7}$ \\
\hline VARIABLES & Sector 18 & Sector 20 & Sector 21 & Sector 22 & Sector 23 & Sector 24 & Sector 25 \\
\hline Capital (ln) & $0.260^{* * *}$ & $0.621^{* * *}$ & 0.162 & $0.426^{* * *}$ & $0.363^{* * *}$ & $0.476^{* * *}$ & $0.482^{* * *}$ \\
& $(0.0596)$ & $(0.0328)$ & $(0.209)$ & $(0.0448)$ & $(0.0659)$ & $(0.0138)$ & $(0.0429)$ \\
Labor (ln) & $1.117^{* * *}$ & $0.597^{* * *}$ & $1.3722^{* * *}$ & $0.789^{* * *}$ & $0.986^{* * *}$ & $0.792^{* * *}$ & $0.490^{* * *}$ \\
& $(0.179)$ & $(0.0577)$ & $(0.368)$ & $(0.0562)$ & $(0.111)$ & $(0.0215)$ & $(0.108)$ \\
Observations & 970 & 1825 & 525 & 2765 & 3770 & 620 & 3360 \\
Wald test statistic of constant returns to scale & 8.442 & 51.99 & 7.319 & 107.8 & 52.50 & 219.6 & 0.0583 \\
Sargan-Hansen test statistic & $4.93 \times 10^{-8}$ & $9.18 \times 10^{-9}$ & & $6.12 \times 10^{-9}$ & $1.82 \times 10^{-8}$ & 6.456 \\
\hline
\end{tabular}


Table 2. Cont.

\begin{tabular}{cccccccc}
\hline VARIABLES & Sector 26 & Sector 27 & Sector 28 & Sector 29 & Sector 30 & Sector 31 & Sector 34 \\
\hline Capital $(\ln )$ & $0.383^{* * *}$ & $0.576^{* * *}$ & $0.472^{* * *}$ & $0.808^{* * *}$ & 0.326 & $0.223^{* * *}$ & $0.228^{* * *}$ \\
& $(0.0528)$ & $(0.0478)$ & $(0.0662)$ & $(0.279)$ & $(0.203)$ & $(0.0680)$ & $(0.0488)$ \\
Labor $(\ln )$ & $0.731^{* * *}$ & $0.620^{* * *}$ & $0.707^{* * *}$ & 0.649 & $1.078^{* *}$ & $0.947^{* * *}$ & $0.925^{* * *}$ \\
& $(0.0963)$ & $(0.0660)$ & $(0.206)$ & $(0.468)$ & $(0.432)$ & $(0.106)$ & $(0.103)$ \\
Observations & 740 & 1040 & 810 & 440 & 570 & 2445 & 930 \\
Wald test statistic of constant returns to scale & 3.370 & 57.84 & 1.351 & 4.571 & 3.010 & 5.093 & 5.511 \\
Sargan-Hansen test statistic & $3.50 \times 10^{-8}$ & $1.59 \times 10^{-8}$ & $2.28 \times 10^{-8}$ & 0.0780 & $1.65 \times 10^{-8}$ & $8.96 \times 10^{-8}$ & $4.04 \times 10^{-9}$ \\
\hline
\end{tabular}

Note: standard errors in parentheses; ${ }^{* * *} p<0.01,{ }^{* *} p<0.05$; Z-test statistics are in parenthesis; Wald test of constant returns to scale; proxy variables: raw material expenses. The test for the over-identifying restrictions is based on Sargan-Hansen's J-test. Manufacturing industry codes are presented in Table 1 (Column 1). Source: authors' estimation from VAES 2010-2015.

From Table 2, we do not find evidence of constant returns to scale in all sectors. Instead, most of them are characterized by increasing returns to scale.

Grounded on this estimated result shown in Table 2, the firm-level TFP was calculated using the command acfest in Stata for the analysis in Section 4.2. Table 3 presents the descriptive statistics of TFP. The highly performing sectors in terms of average productivity in 2010-2015 were wearing apparel (code 14), leather and related products (code 15), furniture (code 31), and the fabricated metal products sectors (code 25). The low-performing sectors were firms in chemicals and chemical products (code 20), electrical equipment (code 27), and food products (code 10).

Table 3. Total factor productivity (TFP) level by industries, 2010-2015.

\begin{tabular}{|c|c|c|c|}
\hline Industry & Mean & Min & Max \\
\hline 10: Food products & 4.994 & -1.771 & 9.278 \\
\hline 11: Beverages & 2.935 & -2.689 & 5.864 \\
\hline 13: Textiles & 5.329 & 0.721 & 9.323 \\
\hline 14: Wearing apparel & 7.890 & 2.236 & 11.760 \\
\hline 15: Leather and related products & 7.853 & 4.165 & 9.941 \\
\hline 16: Wood and products of wood/cork & 5.438 & 1.599 & 7.535 \\
\hline 17: Paper and paper products & 5.651 & -1.692 & 8.535 \\
\hline 18: Printing and reproduction of recorded media & 6.262 & 2.889 & 8.702 \\
\hline 20: Chemicals and chemical products & 4.758 & 0.321 & 8.051 \\
\hline 21: Pharmaceuticals, medicinal chemicals & 6.050 & 2.486 & 10.166 \\
\hline 22: Rubber and plastics products & 5.800 & 0.150 & 8.765 \\
\hline 23: Other non-metallic mineral products & 5.304 & -6.892 & 8.463 \\
\hline 24: Basic metals & 5.045 & 1.590 & 8.549 \\
\hline 25: Fabricated metal products & 6.397 & 1.120 & 9.419 \\
\hline 26: Computer, electronic and optical products & 6.407 & 2.670 & 9.921 \\
\hline 27: Electrical equipment & 4.827 & 0.981 & 6.734 \\
\hline 28: Not-yet-classified machinery and equipment & 5.501 & 1.196 & 7.876 \\
\hline 29: Motor vehicles, trailers and semi-trailers & 2.017 & -1.302 & 3.702 \\
\hline 30: Other transport equipment & 5.309 & -0.262 & 8.138 \\
\hline 31: Furniture & 6.901 & 1.572 & 9.853 \\
\hline 34: Other manufacturing & 7.056 & -0.101 & 9.490 \\
\hline All manufacturing & 5.921 & -6.892 & 11.760 \\
\hline
\end{tabular}

Source: authors' estimation from TFP regressions' results in Table 2, using the command acfest in Stata.

\subsection{Determinants of TFP}

Sample means and standard deviations of variables in the model of TFP determinants are presented in the Supplementary Materials, Table S1.

Table 4 presents the estimation results of the 21 manufacturing sectors. As indicated in the bottom line of Table 4, high levels of autocorrelation do not exist in most manufacturing sectors, as indicated by the second autocorrelation (AR(2)) Arellano-Bond test statistics, which are not significant at the $10 \%$ level, except for sector 10 (food products). In addition, Table 4 also ensures the validity of instrument variables since the Hansen J statistics in the bottom line are not significant at the $10 \%$ level in most manufacturing sectors, except for sectors 14 (wearing apparel), 27 (electrical equipment), and 31 (furniture). 
Table 4. Determinants of TFP by industries, 2010-2015. VA: value-added.

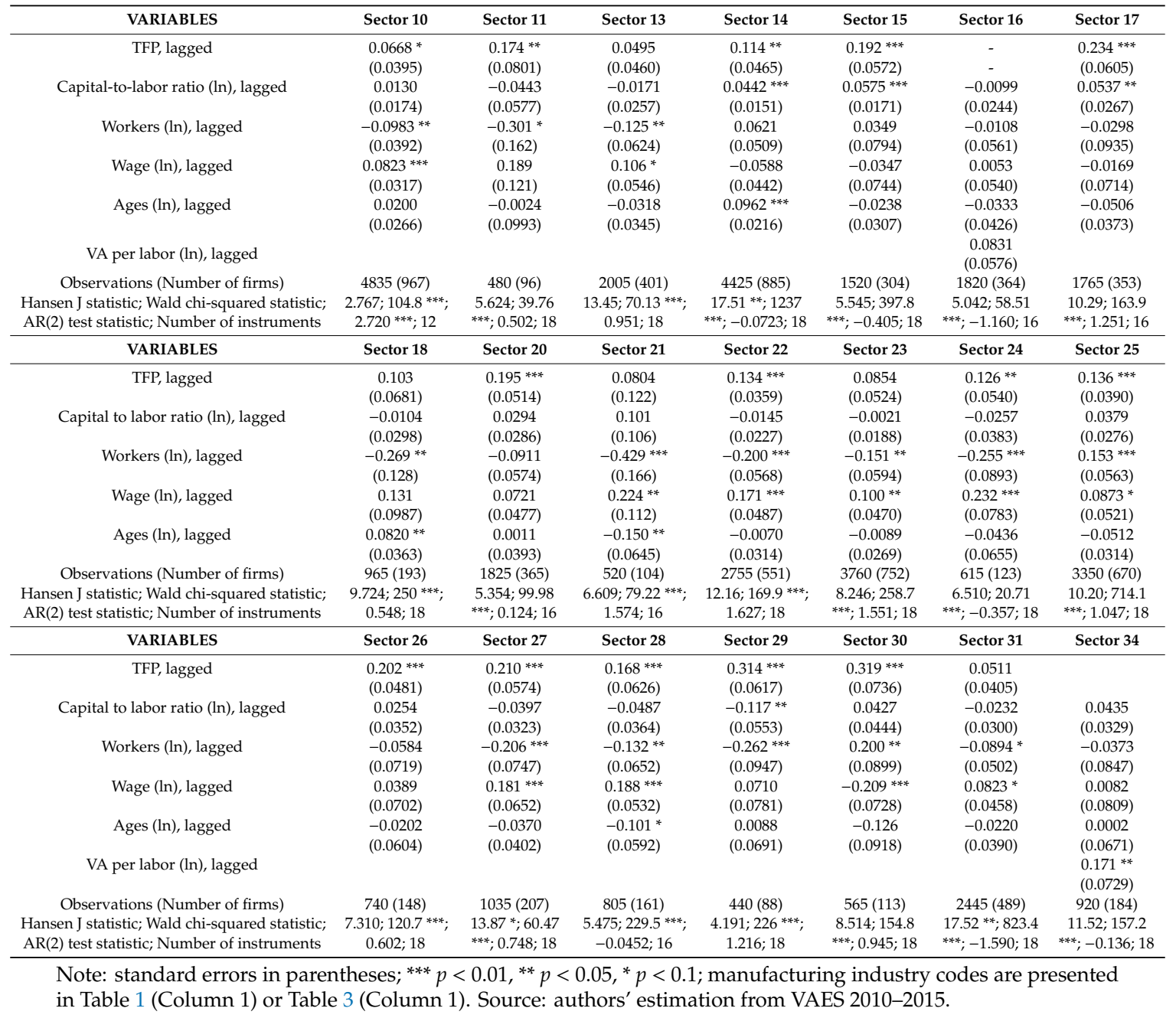

In Table 4, we observe that the estimated coefficients on lagged TFP are significantly positive at the common levels in most sectors, such as beverages (code 11), leather and related products (code 15), paper and paper products (code 17), chemicals and chemical products (code 20), rubber and plastics products (code 22), basic metals (code 24), fabricated metal products (code 25), computer, electronic and optical products (code 26), not-yet-classified machinery and equipment (code 28), motor vehicles, trailers and semi-trailers (code 29), and other transport equipment (code 30). Their magnitudes are from 0.13 to 0.32 , which is relatively small, and these indicate a relatively quick adjustment of firm productivity over time in those sectors (cf. Kim et al. (2009) found a slow adjustment of firm productivity in the Japanese food sector over time). The significantly positive effects are found in every manufacturing sector if classified by, namely: low-tech manufacturing (such as beverages, leather and related products, and paper and paper products); medium low-tech manufacturing (such as fabricated metal products); medium high-tech manufacturing (such as motor vehicles, trailers and semi-trailers, and other transport equipment); and high-tech manufacturing (such as the computer, electronic and optical products) (see the classification in Kim (2018), and Harris and Moffat (2015)).

In Table 4, we observe that larger firms measured by the number of workers are less productive than smaller firms in sectors such as beverages (code 11), textiles (code 13), printing and reproduction of recorded media (code 18), pharmaceuticals and medicinal chemicals (code 21), rubber and plastics products (code 22), other non-metallic mineral products (code 23), basic metals (code 24), not-yet-classified machinery and equipment (code 28), and motor vehicles, trailers and semi-trailers (code 29). This finding is in line with Giang et al. (2019) and Giang et al. (2018) for Vietnamese 
manufacturing small and medium-sized enterprises (SMEs) in 2011-2015, Kreuser and Newman (2018) in South Africa, Fernandes (2008) in Bangladesh, and Söderbom and Teal (2004) in Ghana. Some studies that disaggregated the manufacturing sectors had similar results to ours. For example, the study of Satpathy et al. (2017) in India, which disaggregated into sectors like us, showed that significant positive effects of size are found in sectors such as agricultural and food products, textiles, basic metals, chemical and chemical products, electrical equipment, other transport equipment, pharmaceuticals and medicine, and rubber and plastic. Kim (2018) found that firm size has a positive influence on TFP growth in both low-tech and high-tech manufacturing sectors (at small, medium, and large scales), and a negative influence on both medium-low and medium-high tech manufacturing sectors (at small, medium and large scales) in Japan. However, we also find that larger firms are more productive than smaller firms in some sectors, namely fabricated metal products (code 25) and other transport equipment (code 30). In fact, the effect of firm size on productivity has been investigated intensively and the evidence is mixed. By contrast, Van Biesebroeck (2005) found that larger firms have higher productivity for several African countries.

We also find that older firms are generally more productive than younger ones in the printing and reproduction of recorded media sector (code 18). This is in line with Kreuser and Newman (2018) for the aggregated manufacturing sector in South Africa, and Xu et al. (2019) for the case of the Chinese furniture sector. However, our results also show negative effects in such sectors as pharmaceuticals and medicinal chemicals (code 21) and electrical equipment (code 27), and this is in line with the vintage effect or learning-by-doing effect as suggested by Jovanovic and Nyarko (1994), and the studies of Giang et al. (2019), and Giang et al. (2018) for Vietnamese manufacturing SMEs in 2011-2015.

Firms with higher capital-labor ratios are found to be more productive in some sectors, namely leather and related products (code 15) and paper and paper products (code 17), and this has also been found in Kreuser and Newman (2018) for the aggregated manufacturing sector in South Africa. However, a negative effect is found in motor vehicles, trailers, and semi-trailers (code 29).

Regarding labor quality measured by the average wage level, the higher the level of human capital is, the more productive the firm is. We find a positive association in sectors such as textiles (code 13), pharmaceuticals and medicinal chemicals (code 21), rubber and plastics products (code 22), other non-metallic mineral products (code 23), basic metals (code 24), fabricated metal products (code 25), and not-yet-classified machinery and equipment (code 28). However, a negative relationship between labor quality and productivity is evidenced in other transport equipment (code 30). Mixed evidence was recently also found in the manufacturing-disaggregated study by Kim (2018), who found that average wage has a negative influence on TFP growth in low-tech, medium-low, and medium-high tech manufacturing sectors, and positive one in high-tech manufacturing sectors in Japan.

The level of real value-added per worker of the firm is shown to be passively correlated with TFP only in other manufacturing sectors (code 34). This has also been found in Kreuser and Newman (2018) for the aggregated manufacturing sector in South Africa.

\subsection{Heterogeneity of TFP}

\subsubsection{Labor Heterogeneity}

Table 5 presents the estimation results of the 21 manufacturing sectors across heterogeneous groups in terms of employment size (full results are in Supplementary Materials, Table S2). Relevant tests in the bottom line of Table 5 include tests of high-level autocorrelation and the validity of instrument variables. Specifically, high levels of autocorrelation are not held in most manufacturing sectors as suggested by the AR (2) test statistics, which are not significant at the $10 \%$ level, except for food products (code 10-number of workers between 10-50, and 1000-5000), and other non-metallic mineral products (code 23-number of workers between 50-200). 
Table 5. Labor-heterogeneity determinants of TFP by industries, 2010-2015.

\begin{tabular}{|c|c|c|c|c|c|c|c|}
\hline \multirow{2}{*}{ VARIABLES } & \multicolumn{7}{|c|}{ Workers } \\
\hline & $10-49$ & 50-199 & 200-299 & $300-499$ & 500-999 & $1000-4999$ & $>5000$ \\
\hline \multicolumn{8}{|c|}{ Sector 10: Food products (Number of observations:_1403) } \\
\hline TFP, lagged & 0.0465 & -0.0397 & 0.0938 & $0.211 * *$ & 0.0590 & $0.337^{* * *}$ & \\
\hline Capital to labor ratio (ln), lagged & 0.0227 & -0.0062 & 0.0336 & $0.0814^{* *}$ & 0.0530 & $0.167^{* * *}$ & \\
\hline Workers (ln), lagged & -0.0010 & -0.0603 & 0.0271 & $0.412 * * *$ & -0.0181 & -0.0054 & \\
\hline Wage (ln), lagged & 0.0692 & $0.203 * * *$ & $0.212 * *$ & -0.0417 & 0.0385 & 0.0514 & \\
\hline Ages (ln), lagged & 0.0049 & 0.0086 & 0.0134 & -0.0199 & $0.105^{*}$ & 0.0505 & \\
\hline \multicolumn{8}{|c|}{ Sector 11: Beverages (Number of observations: _107) } \\
\hline VA per labor (ln), lagged & $0.270 * *$ & & & & & & \\
\hline Capital to labor ratio (ln), lagged & $-0.237^{*}$ & -0.106 & & & & & \\
\hline Workers $(\ln )$, lagged & -0.406 & $-0.537^{*}$ & & & & & \\
\hline Wage (ln), lagged & 0.125 & $0.454^{* *}$ & & & & & \\
\hline \multicolumn{8}{|c|}{ Sector 13: Textiles (Number of observations:_542) } \\
\hline TFP, lagged & 0.0018 & & $0.297^{* *}$ & 0.130 & & & \\
\hline Workers $(\ln )$, lagged & $-0.179 *$ & -0.0020 & -0.0437 & -0.180 & & & \\
\hline Wage (ln), lagged & $0.185^{* *}$ & $0.142 *$ & 0.185 & $0.308^{* *}$ & & & \\
\hline Ages (ln), lagged & $-0.116 * *$ & 0.0125 & 0.0121 & -0.0295 & & & \\
\hline \multicolumn{8}{|c|}{ Sector 14: Wearing apparel (Number of observations:_332) } \\
\hline VA per labor $(\ln )$, lagged & 0.209 & 0.0572 & & 0.0982 & $0.225^{* * *}$ & & \\
\hline Capital to labor ratio (ln), lagged & 0.0838 & $0.0860 * * *$ & 0.0228 & $0.105^{* * *}$ & 0.0338 & 0.0485 & 0.120 \\
\hline Workers $(\ln )$, lagged & 0.175 & 0.146 & $0.254 * *$ & $0.486^{* * *}$ & $0.335^{* * *}$ & 0.134 & -0.141 \\
\hline Wage (ln), lagged & $-0.0050(0.179)$ & 0.106 & 0.136 & $-0.168 *$ & $-0.188^{* * *}$ & -0.0986 & 0.302 ** \\
\hline Ages (ln), lagged & 0.0843 & 0.0103 & $0.117^{* *}$ & 0.0787 & $0.0995^{* *}$ & $0.100 * * *$ & 0.0037 \\
\hline TFP, lagged & & & 0.0770 & & & 0.163 & -0.216 \\
\hline \multicolumn{8}{|c|}{ Sector 15: Leather and related products (Number of observations: _92) } \\
\hline TFP, lagged & $0.566^{* *}$ & 0.172 & 0.167 & & -0.0011 & & \\
\hline Capital to labor ratio (ln), lagged & 0.0876 & 0.0590 & $0.0682 *$ & 0.0439 & $0.120 * *$ & 0.0109 & 0.0673 \\
\hline Workers $(\ln )$, lagged & $0.615 * *$ & 0.119 & 0.188 & -0.0628 & 0.262 & $0.190 *$ & -0.0556 \\
\hline Wage (ln), lagged & $-0.386 * *$ & 0.0399 & 0.205 & $0.352 * *$ & 0.0526 & -0.122 & 0.0141 \\
\hline Ages $(\ln )$, lagged & -0.116 & $-0.111 *$ & $-0.121 *$ & 0.0205 & 0.0371 & -0.0291 & 0.0737 \\
\hline VA per labor $(\ln )$, lagged & & & & -0.0187 & & $0.161 * *$ & 0.134 \\
\hline \multicolumn{8}{|c|}{ Sector 16: Wood and products of wood/cork (Number of observations: _733) } \\
\hline TFP, lagged & 0.0808 & $0.254^{* * *}$ & $0.360 *$ & & & & \\
\hline Capital to labor ratio $(\ln )$, lagged & 0.0460 & 0.0544 * & 0.0804 & & & & \\
\hline Workers $(\ln )$, lagged & 0.128 & $0.241^{* *}$ & $0.456^{* *}$ & & & & \\
\hline Sector 17: Paper and paper products & umber of observ & ons: _630) & & & & & \\
\hline TFP, lagged & $0.208^{* *}$ & $0.188^{*}$ & $0.347 * * *$ & $0.392 * * *$ & & & \\
\hline Capital to labor ratio (ln), lagged & 0.0429 & 0.0145 & $0.214^{* * *}$ & $0.192 * * *$ & & & \\
\hline Workers $(\ln )$, lagged & 0.0705 & 0.0527 & $0.384 * *$ & 0.329 & & & \\
\hline Wage (ln), lagged & 0.0699 & 0.0416 & -0.0996 & $-0.275 *$ & & & \\
\hline Ages (ln), lagged & -0.0466 & -0.0548 & $-0.167^{* *}$ & $0.153 *$ & & & \\
\hline Sector 18: Printing and reproduction & recorded media & umber of obser & ations:_472) & & & & \\
\hline VA $(\ln )$, lagged & $0.194^{* *}$ & 0.0975 & & & & & \\
\hline Workers $(\ln )$, lagged & -0.166 & $-0.279 * *$ & & & & & \\
\hline Wage (ln), lagged & 0.0455 & $0.198 * *$ & & & & & \\
\hline Sector 20: Chemicals and chemical pr & ucts (Number of & oservations: _7 & & & & & \\
\hline TFP, lagged & $0.271^{* * *}$ & & $0.334 *$ & 0.0715 & & & \\
\hline Capital to labor ratio (ln), lagged & 0.0704 & -0.0777 & -0.0063 & 0.0550 & $-0.282 * *$ & & \\
\hline VA per labor (ln), lagged & & $0.147^{*}$ & & & $0.450^{* * *}$ & & \\
\hline Sector 21: Pharmaceuticals, medicina & nemicals (Numb & of observations & -208) & & & & \\
\hline Ages (ln), lagged & $-0.210 * *$ & -0.0928 & & & & & \\
\hline VA per labor (ln), lagged & & $0.340 * *$ & & & & & \\
\hline Sector 22: Rubber and plastics produ & (Number of obse & rations:_737) & & & & & \\
\hline VA per labor (ln), lagged & 0.0901 & $0.114^{* *}$ & & & & & \\
\hline Capital to labor ratio (ln), lagged & $-0.142^{* * *}$ & -0.0257 & 0.0403 & 0.0889 & 0.0706 & & \\
\hline Workers $(\ln )$, lagged & $-0.289 * *$ & -0.0764 & -0.0199 & -0.0010 & -0.159 & & \\
\hline Wage (ln), lagged & $0.317^{* * *}$ & $0.160 * * *$ & $0.302 * * *$ & -0.108 & 0.0174 & & \\
\hline Ages (ln), lagged & -0.0576 & -0.0809 & -0.0062 & -0.0340 & 0.0222 & & \\
\hline TFP, lagged & & & $0.187 *(0.110)$ & $0.256^{* * *}(0.0899)$ & $0.0380(0.271)$ & & \\
\hline Sector 23: Other non-metallic minera & roducts (Number & f observations: & 986) & & & & \\
\hline VA per labor (ln), lagged & 0.0947 & & 0.0200 & & & & \\
\hline Capital to labor ratio (ln), lagged & -0.0592 & 0.0222 & 0.0454 & 0.0336 & $0.179 * * *$ & & \\
\hline Workers $(\ln )$, lagged & -0.0914 & 0.0062 & 0.126 & $0.303 *$ & $0.337 * *$ & & \\
\hline Wage (ln), lagged & $0.115 *$ & 0.111 & $0.293 * *$ & 0.0108 & -0.0114 & & \\
\hline Ages (ln), lagged & $-0.135 * *$ & $0.104^{* * *}$ & 0.0690 & -0.0864 & -0.0331 & & \\
\hline TFP, lagged & & $0.139 *$ & & $0.219^{* *}$ & 0.171 & & \\
\hline Sector 24: Basic metals (Number of ol & rvations:_243) & & & & & & \\
\hline VA per labor (ln), lagged & 0.184 & & & & & & \\
\hline Capital to labor ratio (ln), lagged & -0.0893 & -0.0187 & & & & & \\
\hline Workers (ln), lagged & -0.213 & 0.216 & & & & & \\
\hline Wage $(\ln )$, lagged & 0.238 & $0.162(0.146)$ & & & & & \\
\hline Ages $(\ln )$, lagged & -0.0415 & $-0.285^{*}$ & & & & & \\
\hline TFP, lagged & & 0.115 & & & & & \\
\hline
\end{tabular}


Table 5. Cont.

\begin{tabular}{|c|c|c|c|c|c|c|c|}
\hline \multirow{2}{*}{ VARIABLES } & \multicolumn{7}{|c|}{ Workers } \\
\hline & $10-49$ & 50-199 & 200-299 & $300-499$ & 500-999 & 1000-4999 & $>5000$ \\
\hline \multicolumn{8}{|c|}{ Sector 25: Fabricated metal products (Number of observations: _1492) } \\
\hline TFP, lagged & $0.248^{* * *}$ & $0.147 *$ & 0.218 & & -0.0666 & & \\
\hline Capital to labor ratio (ln), lagged & $0.118 * *$ & 0.0069 & 0.0168 & -0.0768 & 0.0413 & & \\
\hline Workers $(\ln )$, lagged & $0.375^{* * *}$ & 0.0772 & 0.0972 & 0.137 & $0.210 *$ & & \\
\hline Wage (ln), lagged & -0.0431 & $0.144 *$ & 0.0251 & -0.0452 & $0.0257(0.108)$ & & \\
\hline \multicolumn{8}{|c|}{ Sector 26: Computer, electronic and optical products (Number of observations:_217) } \\
\hline TFP, lagged & $0.338^{* * *}$ & $0.280 * * *$ & 0.108 & 0.135 & & & \\
\hline Wage $(\ln )$, lagged & -0.194 & -0.173 & $0.285^{* *}$ & 0.0049 & & & \\
\hline \multicolumn{8}{|c|}{ Sector 27: Electrical equipment (Number of observations: _235) } \\
\hline TFP, lagged & $0.173^{* *}$ & $0.175^{* *}$ & $0.525^{* * *}$ & & & & \\
\hline Capital to labor ratio (ln), lagged & -0.111 & -0.0206 & 0.0193 & $-0.267 * *$ & & & \\
\hline Workers $(\ln )$, lagged & $-0.423 * *$ & $-0.227 * *$ & $0.296 *(0.161)$ & 0.0439 & & & \\
\hline Wage $(\ln )$, lagged & $0.373^{* * *}$ & $0.254^{* * *}$ & $-0.104(0.123)$ & -0.0420 & & & \\
\hline Ages (ln), lagged & $-0.283 * *$ & -0.0403 & 0.0891 & 0.100 & & & \\
\hline VA per labor $(\ln )$, lagged & & & & $0.343 * * *$ & & & \\
\hline \multicolumn{8}{|c|}{ Sector 28: Not-yet-classified machinery and equipment (Number of observations: _364) } \\
\hline TFP, lagged & 0.0686 & $0.266 *$ & & & & & \\
\hline Wage (ln), lagged & $0.228 * * *$ & 0.152 & & & & & \\
\hline Ages $(\ln )$, lagged & $0.128(0.0848)$ & $\begin{array}{l}-0.0236 \\
(0.0753)\end{array}$ & & & & & \\
\hline \multicolumn{8}{|c|}{ Sector 30: Other transport equipment $\left(\mathrm{N}=\_113\right)$} \\
\hline VA per labor $(\ln )$, lagged & & $\begin{array}{l}0.184 \text { ** } \\
(0.0821)\end{array}$ & & & & & \\
\hline \multicolumn{8}{|c|}{ Sector 31: Furniture (Number of observations: _403) } \\
\hline TFP, lagged & -0.208 & 0.0807 & 0.0056 & 0.0240 & $0.268 * * *$ & 0.0736 & \\
\hline Capital to labor ratio (ln), lagged & 0.0306 & -0.0441 * & -0.0657 & $0.0964 * *$ & 0.0618 & -0.0805 & \\
\hline Workers $(\ln )$, lagged & -0.0107 & -0.0031 & -0.0089 & -0.0256 & $0.254 * *$ & 0.219 & \\
\hline Wage $(\ln )$, lagged & 0.177 & $0.174^{* *}$ & $0.298 * * *$ & $0.220 * * *$ & -0.0457 & -0.0548 & \\
\hline Ages $(\ln )$, lagged & $-0.156^{*}$ & -0.0551 & -0.0138 & 0.0752 & 0.165 & $-0.169 * *$ & \\
\hline \multicolumn{8}{|c|}{ Sector 34: Other manufacturing sectors (Number of observations: _175) } \\
\hline TFP, lagged & 0.0477 & 0.0391 & 0.146 & 0.227 & $0.330^{* * *}$ & & \\
\hline Capital to labor ratio $(\ln )$, lagged & 0.0324 & $0.108^{* *}$ & 0.0704 & -0.00101 & 0.0771 & 0.0814 & \\
\hline Wage $(\ln )$, lagged & 0.119 & $0.183 *$ & $0.360^{*}$ & -0.218 & 0.0206 & $-0.218^{* *}$ & \\
\hline VA per labor $(\ln )$, lagged & & & & & & $\begin{array}{l}0.322 * * * \\
(0.0788)\end{array}$ & \\
\hline
\end{tabular}

On top of that, the validity of instrument variables based on Hansen J statistics is observed in most manufacturing sectors, except for wearing apparel (code 14-number of workers between 10-200, 300-500, and 1000-5000), wood and products of wood/cork (code 16-number of workers between 10-200), paper and paper products (code 17-laborers between 10-200). The excluding list is continued with chemicals and chemical products (code 20-number of workers between 200-300, and 500-1000), rubber and plastics products (code 22-number of workers between 10-50, and 200-300), other non-metallic mineral products (code 23-number of workers between 10-200), fabricated metal products (code 25-number of workers between 10-50, and between 200-300), furniture (code 31-number of workers between 10-50, and 1000-5000), and other manufacturing sectors (code 34-number of workers between 10-50).

In the following part, we discuss the significant findings. Table 5 shows that firms' size is statistically significantly positive in food products (code 10-number of workers between 300-500), wearing apparel (code 14-number of workers between 200-1000), leather and related products (code 15-number of workers between 10-50 and between 1000-5000), wood and products of wood/cork (code 16-number of workers between 200-300), paper and paper products (code 17-laborers between 200-300), and furniture (code 31-number of workers between 500-1000). Besides, two sectors belonged to medium low-tech manufacturing, showing statistically significant positive effects in (1) other non-metallic mineral products (code 23-number of workers between 300-500 and between 500-5000); and (2) fabricated metal products (code 25-number of workers between 500-1000). Moreover, the sector of electrical equipment (code 27) that belonged to medium high-tech manufacturing has evidence of a statistically significant positive effect for firms with number of workers between 
200-300. Similar results can also be found in Kreuser and Newman (2018), although these authors conducted their research for the aggregated manufacturing sector in South Africa and the classification of a firm's size by number workers is not the same with us. Productivity heterogeneity in labor was discovered in Kim (2018), who found that large firms are associated with higher productivity in low-technology, medium-low-technology, and medium-high-technology manufacturing sectors, but with lower productivity in the high-technology manufacturing sector.

A statistically negative effect of a firm's size is observed in printing and reproduction of recorded media (code 18-number of workers between 50-200), which belongs to the low-tech manufacturing sector, and in electrical equipment (code 27-number of workers between 10-50 and 50-200), which belongs to the medium high-tech manufacturing sector. Giang et al. (2018) found a negative effect in the sector of metal and machinery products for Vietnamese manufacturing SMEs in 2011-2015.

Regarding labor quality measured by average wage, Table 5 shows that firms' average wage is statistically significantly positive in food products (code 10-number of workers between 50-300), beverages (code 11-number of workers between 50-200), textiles (code 13-number of workers between 10-200 and 300-500), wearing apparel (code 14-number of workers more than 5000), leather and related products (code 15-number of workers between 10-50), printing and reproduction of recorded media (code 18-number of workers between 50-200), and furniture (code 31-number of workers between 200-500). All of the sectors above belong to the low-tech manufacturing sector. Besides, regarding the medium low-tech manufacturing sectors, the firms' size is statistically significantly positive in other non-metallic mineral products (code 23-number of workers between 200-300), and fabricated metal products (code 25-number of workers between 50-200). Besides, concerning the medium high-tech manufacturing sector, the firms' size is statistically significantly positive in electrical equipment (code 27-number of workers between 10-200), not-yet-classified machinery and equipment (code 28-number of workers between 10-50). In relation to the high-tech manufacturing sector, the firms' size is statistically significantly positive in the computer, electronic and optical products (code 26-number of workers between 200-300). Productivity heterogeneity in labor quality has been discovered in Kim (2018), who has found that lower-wage level is associated with lower productivity in low-technology, medium-low-technology, medium-high-technology, and high-technology manufacturing sectors in Japan.

A statistically negative effect of labor quality is observed in low-tech manufacturing sectors such as leather and related products (code 15-number of workers between 300-500), and paper and paper products (code 17-number of workers between 300-500).

With respect to firms' age, Table 5 shows that the firms' age is statistically significantly positive in food products (code 10-number of workers between 500-1000), wearing apparel (code 14-number of workers between 200-300, and 500-1000), and paper and paper products (code 17-number of workers between 300-500). Only one sector belonged to medium low-tech manufacturing sectors, namely other non-metallic mineral products (code 23-number of workers between 50-200), and basic metals (code 24-number of workers between 50-200), the signals are statistically significantly positive effects. That is in line with Xu et al. (2019) for the case of the Chinese furniture sector. However, the statistically negative effect is observed in textiles (code 13-with workers between 10-50), leather and related products (code 15-number of workers between 50-300), paper and paper products (code 17-number of workers between 50-300). That being said, all have belonged to the low-tech manufacturing sector. In addition, the medium high-tech manufacturing sectors such as electrical equipment (code 27-number of workers between 10-50) also accompanies a statistically negative effect. Besides, the high-tech manufacturing sector, namely pharmaceuticals, medicinal chemicals (code 21—number of workers between 10-50) shows a statistically negative effect.

With reference to the firms' lagged total factor productivity, Table 5 shows that the firms' lagged total factor productivity is statistically significantly positive in food products (code 10-number of workers between 300-500), textiles (code 13-number of workers between 200-300), leather and related 
products (code 15-number of workers between 10-50), paper and paper products (code 17-number of workers between 200-500), furniture (code 31-number of workers between 500-1000). Besides, about medium low-tech manufacturing sectors, namely rubber and plastics products (code 22-number of workers between 300-500), other non-metallic mineral products (code 23-number of workers between 50-200, and 300-500), and fabricated metal products (code 25-number of workers between 50-200), there exist a statistically significantly positive effect. On top of that, medium high-tech manufacturing sectors such as chemicals and chemical products (code 20-number of workers between 10-50), electrical equipment (code 27-number of workers between 10-300), and not-yet-classified machinery and equipment (code 28-number of workers between 50-200) also go in line with a statistically significantly positive effect. Besides, the high-tech manufacturing sector, namely computer, electronic, and optical products (code 26-number of workers between 10-200) obtains a statistically positive effect.

In relation to firms' capital-to-labor ratio, Table 5 shows that the firms' capital intensity is statistically significantly positive in food products (code 10-number of workers between 300-500, and 1000-5000), wearing apparel (code 14-number of workers 50-200, and 300-500), leather and related products (code 15-number of workers between 200-300, and 500-1000), wood and products of wood/cork (code 16-number of workers between 50-200), paper and paper products (code 17-number of workers between 200-500); and furniture (code 31-number of workers between 300-500). Two sectors belonged to medium low-tech manufacturing sectors, namely other non-metallic mineral products (code 23-number of workers between 500-1000), and fabricated metal products (code 25-number of workers between 10-50) show significantly positive effects. However, a statistically negative effect of the firms' capital intensity is observed in beverages (code 11-number of workers between 10-50), and rubber and plastics products (code 22-number of workers between 10-50). Medium high-tech manufacturing sectors, including chemicals and chemical products (code 20-number of workers between 500-1000), and electrical equipment (code 27-number of workers between 300-500) are found with statistically negative effects.

The level of real value-added per worker of the firms is shown to be passively correlated with TFP only in beverages (code 11-number of workers between 10-50); in wearing apparel (code 14-number of workers between 500-1000); in leather and related products (code 15-number of workers between 1000-5000); and in rubber and plastics products (code 22-number of workers between 50-200). With respect to medium high-tech manufacturing sectors, three sectors, namely chemicals and chemical products (code 20-number of workers between 50-200), electrical equipment (code 27-number of workers between 300-500), and other transport equipment (code 30-number of workers between 50-200) are also accompanied by a negative relationship.

\subsubsection{Capital Stock Heterogeneity}

Table 6 presents the estimation results of the 21 manufacturing sectors across groups of fixed capital (full results are in the Supplementary Materials, Table S3). Similar tests in were conducted Sections 4.2 and 4.3.1 to examine the existence of high levels of autocorrelation and the validity of instrument variables. The results in Table 6 indicate that the first problem does not hold in most manufacturing sectors, except for food products (code 10-fixed capital between 200-500 Vietnamese Dong (VND) billion), leather and related products (code 15-fixed capital between 10-50 VND billion), wood and products of wood/cork (code 16-fixed capital less than 10 VND billion), and other non-metallic mineral products (code 23-fixed capital less than 10 VND billion).

In addition, the second problem is solved in most manufacturing industries, except for wearing apparel (code 14-fixed capital less than 50 VND billion), leather and related products (code 15-fixed capital between 10-50 VND billion), wood and products of wood/cork (code 16-fixed capital less than 50 VND billion and between 200-500 VND billion), and printing and reproduction of recorded media (code 18-fixed capital between 50-200 VND billion). The list also includes some more sectors, such as chemicals and chemical products (code 20-fixed capital less than 10 VND billion), pharmaceuticals 
and medicinal chemicals (code 21-fixed capital less than $10 \mathrm{VND}$ billion), rubber and plastics products (code 22-fixed capital between 50-500 VND billion), other non-metallic mineral products (code 23-fixed capital less than 10 VND billion), fabricated metal products (code 25-fixed capital less than 10 VND billion), and computer, electronic and optical products (code 26-fixed capital between 50-200 VND billion).

Table 6. Capital-heterogeneity determinants of TFP by industries, 2010-2015.

\begin{tabular}{|c|c|c|c|c|c|}
\hline \multirow[b]{2}{*}{ VARIABLES } & \multicolumn{5}{|c|}{ Total Fixed Capital } \\
\hline & $\begin{array}{l}<10 \text { VND } \\
\text { Billion }\end{array}$ & $\begin{array}{l}\text { From } 10 \text { to Less than } \\
50 \text { VND Billion }\end{array}$ & $\begin{array}{l}\text { From } 50 \text { to Less than } \\
200 \text { VND Billion }\end{array}$ & $\begin{array}{l}\text { From } 200 \text { to Less than } \\
500 \text { VND Billion }\end{array}$ & $\begin{array}{l}>500 \text { VND } \\
\text { Billion }\end{array}$ \\
\hline \multicolumn{6}{|c|}{ Sector 10: Food products (Number of observations:_838) } \\
\hline Capital to labor ratio (ln), lagged & -0.0345 & 0.0543 & 0.0462 & 0.0305 & $0.280^{* * * *}$ \\
\hline Workers $(\ln )$, lagged & -0.127 & -0.0121 & 0.0512 & $-0.318^{* * *}$ & -0.0038 \\
\hline Wage (ln), lagged & $0.225 * * *$ & $0.0958 * *$ & 0.0453 & $0.237 * *$ & 0.0193 \\
\hline TFP, lagged & & & $0.109 *$ & & 0.167 \\
\hline \multicolumn{6}{|c|}{ Sector 11: Beverages Number of observations: _87) } \\
\hline TFP, lagged & $0.320^{* * *}$ & & $0.516^{* * *}$ & & \\
\hline Workers $(\ln )$, lagged & 0.0387 & $-0.598 * *$ & 0.0005 & & \\
\hline Wage (ln), lagged & 0.153 & $0.479 * *$ & 0.0278 & & \\
\hline \multicolumn{6}{|c|}{ Sector 13: Textiles (Number of observations: _461) } \\
\hline VA per labor $(\ln )$, lagged & -0.0873 & & & & \\
\hline Capital to labor ratio $(\ln )$, lagged & $-0.121 * *$ & 0.0357 & 0.0613 & -0.0890 & $0.0921 *$ \\
\hline Workers $(\ln )$, lagged & $-0.428^{* * *}$ & -0.0487 & 0.132 & -0.240 & -0.0838 \\
\hline Wage (ln), lagged & $0.411 * * *$ & 0.0713 & -0.0171 & 0.157 & 0.0496 \\
\hline TFP, lagged & & 0.100 & $0.147^{* *}$ & 0.0231 & $0.174 *$ \\
\hline \multicolumn{6}{|c|}{ Sector 14: Wearing apparel (Number of observations:_1016) } \\
\hline TFP, lagged & $-0.179 *$ & & & & 0.0224 \\
\hline Capital to labor ratio $(\ln )$, lagged & 0.0450 & $-3.33 \mathrm{e}-06$ & $0.0580 *$ & 0.0538 & $0.187^{* *}$ \\
\hline Workers (ln), lagged & $-0.223 *$ & 0.0904 & -0.0606 & $0.335 *$ & 0.0394 \\
\hline Wage (ln), lagged & $0.322 * * *$ & $-0.133 * *$ & -0.0304 & $-0.428 * * *$ & -0.105 \\
\hline Ages (ln), lagged & 0.0553 & $0.0977^{* * *}$ & 0.0488 & $0.123 * * *$ & $0.130 *$ \\
\hline VA per labor (ln), lagged & & $0.133 *$ & $0.184^{* * *}$ & $0.385^{* * *}$ & \\
\hline \multicolumn{6}{|c|}{ Sector 15: Leather and related products (Number of observations:_249) } \\
\hline TFP, lagged & 0.0372 & $0.315^{* * *}$ & 0.101 & -0.0387 & \\
\hline Capital to labor ratio $(\ln )$, lagged & 0.0521 & 0.0469 & 0.0940 & -0.0917 & $0.235^{* *}$ \\
\hline Workers $(\ln )$, lagged & -0.0628 & -0.0140 & $0.202 *$ & $-0.344 * *$ & $-0.165 *$ \\
\hline Wage (ln), lagged & 0.110 & 0.0423 & $-0.154 *$ & 0.163 & 0.120 \\
\hline \multicolumn{6}{|c|}{ Sector 16: Wood and products of wood/cork (Number of observations:_604) } \\
\hline TFP, lagged & & $0.174^{* *}$ & 0.145 & 0.381 & \\
\hline \multicolumn{6}{|c|}{ Sector 17: Paper and paper products (Number of observations:_224) } \\
\hline TFP, lagged & 0.364 & & $0.305^{* *}$ & $0.530^{* * *}$ & 0.0651 \\
\hline Capital to labor ratio (ln), lagged & 0.0113 & 0.0541 & $0.153 * *$ & $0.325 * *$ & $0.424 * *$ \\
\hline Workers $(\ln )$, lagged & 0.178 & $-0.175^{*}$ & 0.265 & 0.160 & -0.0413 \\
\hline Ages $(\ln )$, lagged & -0.0046 & 0.0460 & $-0.187^{* *}$ & -0.0568 & 0.125 \\
\hline \multicolumn{6}{|c|}{ Sector 18: Printing and reproduction of recorded media (Number of observations:_379) } \\
\hline TFP, lagged & 0.0957 & $0.126^{*}$ & & & \\
\hline Capital to labor ratio (ln), lagged & -0.0270 & -0.0927 & -0.0862 & & \\
\hline Workers $(\mathrm{ln})$, lagged & $-0.305^{*}$ & $-0.433^{* * *}$ & $-0.440 *$ & & \\
\hline Wage (ln), lagged & 0.169 & $0.228 * *$ & -0.0076 & & \\
\hline Ages $(\ln )$, lagged & $0.0781 *$ & 0.107 * & -0.0300 & & \\
\hline Value-added per labor $(\ln )$, lagged & & & $0.454 *$ & & \\
\hline \multicolumn{6}{|c|}{ Sector 20: Chemicals and chemical products (Number of observations: _209) } \\
\hline TFP, lagged & -0.0071 & $0.239 * * *$ & & $0.397 * * *$ & -0.0125 \\
\hline Workers $(\ln )$, lagged & -0.121 & 0.0031 & -0.0456 & -0.0098 & $-0.291 * *$ \\
\hline Ages $(\ln )$, lagged & $0.210 *$ & -0.108 & -0.0095 & -0.0305 & 0.0043 \\
\hline VA per labor $(\ln )$, lagged & & & $0.312 * * *$ & & \\
\hline \multicolumn{6}{|c|}{ Sector 21: Pharmaceuticals, medicinal chemicals (Number of observations:_85) } \\
\hline TFP, lagged & -0.229 & $0.339^{* *}$ & & & \\
\hline Capital to labor ratio (ln), lagged & 0.0884 & 0.0061 & $0.299 * *$ & & \\
\hline Workers $(\ln )$, lagged & -0.782 & -0.274 & $-0.550 * * *$ & & \\
\hline Wage $(\ln )$, lagged & $0.784^{* *}$ & 0.0700 & 0.224 * & & \\
\hline Ages (ln), lagged & -0.154 & -0.0488 & $-0.271^{* * *}$ & & \\
\hline VA per labor $(\ln )$, lagged & & & $-0.203 *$ & & \\
\hline \multicolumn{6}{|c|}{ Sector 22: Rubber and plastics products (Number of observations: _228) } \\
\hline VA per labor $(\ln )$, lagged & 0.126 & & $0.138^{*}$ & & \\
\hline Capital to labor ratio $(\mathrm{ln})$, lagged & $-0.139 * * *$ & -0.0984 ** & 0.0201 & 0.0586 & $0.180 *$ \\
\hline Workers $(\ln )$, lagged & -0.190 & $-0.247^{* *}(0.0964)$ & -0.0987 & -0.221 & $-0.409 * *$ \\
\hline Wage (ln), lagged & 0.219 & $0.229 * * *$ & 0.0775 & 0.0850 & $0.305^{* *}$ \\
\hline Ages (ln), lagged & 0.0941 & $-0.130 * *$ & -0.0239 & -0.0570 & 0.0618 \\
\hline TFP, lagged & & 0.0776 & & 0.145 & $0.162 *$ \\
\hline
\end{tabular}


Table 6. Cont.

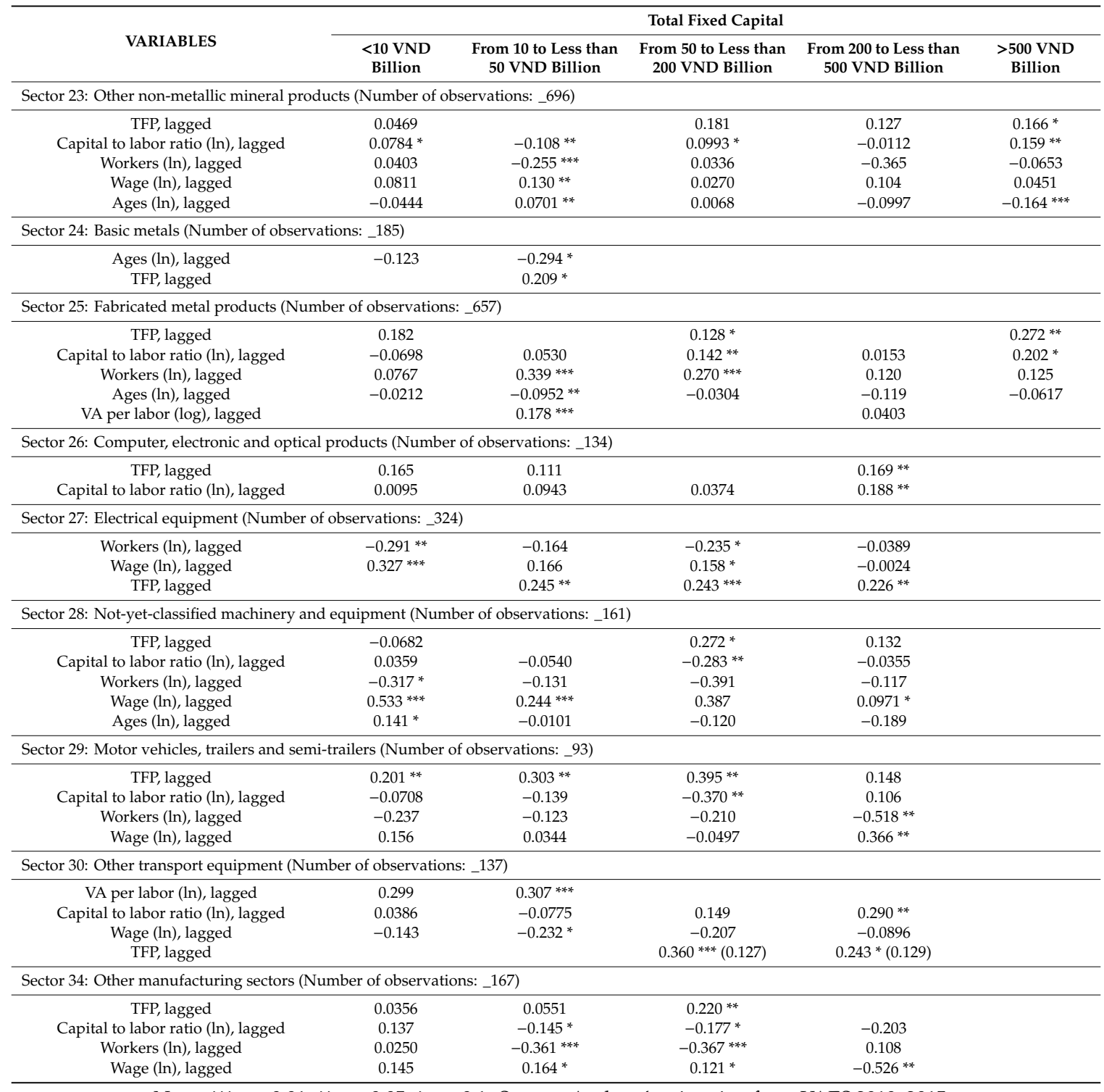

Note: ${ }^{* * *} p<0.01,{ }^{* *} p<0.05,{ }^{*} p<0.1$. Source: Authors' estimation from VAES 2010-2015.

In the following part, we discuss the significant findings. Table 6 shows that firms' size is statistically significantly positive in wearing apparel (code 14-fixed capital between 200-500 VND billion), leather and related products (code 15-fixed capital between 50-200 VND billion), and fabricated metal products (code 25-fixed capital between 10-200 VND billion). However, the statistically negative effect is observed in beverages (code 11-fixed capital between 10-50 VND billion), textiles (code 13-fixed capital less than 10 VND billion), leather and related (code 15-fixed capital larger than 200 VND billion), paper and paper products (code 17-fixed capital between 10-50 VND billion), printing and reproduction of recorded media (code 18-fixed capital up to $50 \mathrm{VND}$ billion), and rubber and plastics products (code 22-fixed capital between 50-200 VND billion and larger than 500 VND billion). In terms of the medium low-tech manufacturing sector, other non-metallic mineral products (code 23-fixed capital between 10-50 VND billion) also show a significant negative effect. Besides, the medium high-tech manufacturing sectors chemicals and chemical products (code 20-fixed capital larger than 500 VND billion), electrical equipment (code 27-fixed capital less than 10 VND billion and in the range 50-200 VND billion), not-yet-classified machinery and equipment (code 28-fixed capital less than 10 VND billion), and motor vehicles, trailers and semi-trailers (code 29-fixed capital 
between $200-500$ VND billion) are in line with a significantly negative correlation. Moreover, the high-tech manufacturing sector, namely pharmaceuticals and medicinal chemicals (code 21-fixed capital between 50-200 VND billion), obtains a statistically negative effect.

As for labor quality measured by average wage, Table 6 shows that firms' size is statistically significantly positive in food products (code 10-fixed capital up to $50 \mathrm{VND}$ billion), beverages (code 11-fixed capital between 10-50 VND billion), textiles (code 13-fixed capital up to 10 VND billion), printing and reproduction of recorded media (code 18-fixed capital between 10-50 VND billion), and rubber and plastics products (code 22-fixed capital between 10-50 VND billion and larger than $500 \mathrm{VND}$ billion). In terms of medium high-tech manufacturing sectors, electrical equipment (code 27-fixed capital less than 10 VND billion and between 50-200 VND billion), not-yet-classified machinery and equipment (code 28-fixed capital less than 50 VND billion and between 200-500 VND billion), and motor vehicles, trailers and semi-trailers (code 29-fixed capital between 200-500 VND billion) also have a significantly positive effect. In addition, the high-tech manufacturing sector, namely pharmaceuticals and medicinal chemicals (code 21-fixed capital between 50-200 VND billion) obtains a significantly positive effect. However, a statistically negative effect is observed in wearing apparel (code 14-fixed capital between 200-500 VND billion) and leather and related products (code 15-fixed capital between 10-50 VND billion). Moreover, in terms of the medium low-tech manufacturing sector, other non-metallic mineral products (code 23-fixed capital between 10-50 VND billion), and in terms of medium high-tech manufacturing sector, other transport equipment (code 30-fixed capital between 10-50 VND billion), are associated with statistically negative effects.

With regard to firms' age, Table 6 shows that firms' age is statistically significantly positive in wearing apparel (code 14-fixed capital larger than $200 \mathrm{VND}$ billion) and printing and reproduction of recorded media (code 18-fixed capital between 10-50 VND billion). In addition, other non-metallic mineral products (code 23-fixed capital between 10-50 VND billion), which belong to the medium low-tech manufacturing sector, and not-yet-classified machinery and equipment (code 28-fixed capital less than 10 VND billion), which belong to the high-tech manufacturing sector, are also affiliated with significantly positive effects. However, a statistically negative effect is observed in leather and related products (code 15-fixed capital between 50-200 VND billion) and rubber and plastics products (code 22-fixed capital between 10-50 VND billion). The negative signs are also found in the medium low-tech manufacturing sectors, such as other non-metallic mineral products (code 23-fixed capital more than 500 VND billion), basic metals (code 24-fixed capital between 10-50 VND billion), and fabricated metal products (code 25-fixed capital between 10-50 VND billion). Only one high-tech manufacturing sector, namely pharmaceuticals and medicinal chemicals (code 21-fixed capital between 50-200 VND billion) observes a statistically negative effect.

Regarding firms' lagged total factor productivity, Table 6 shows that the firms' lagged total factor productivity is statistically significantly positive in food products (code 10-fixed capital between 50-200 VND billion), beverages (code 11-fixed capital less than 10 VND billion and in the range 50-200 VND billion), textiles (code 13-fixed capital between 50-200 VND billion and larger than 500 VND billion), and paper and paper products (code 17-fixed capital between 50-200 VND billion). The list further includes printing and reproduction of recorded media (code 18-fixed capital between 10-50 VND billion), rubber and plastics products (code 22-fixed capital larger than 500 VND billion), and fabricated metal products (code 25-fixed capital between 50-200 VND billion and more than 500 VND billion). In addition, two medium low-tech manufacturing sectors, including other non-metallic mineral products (code 23-fixed capital larger than 500 VND billion) and basic metals (code 24-fixed capital between 10-50 VND billion) have significantly positive effects. Moreover, several medium high-tech manufacturing sectors, such as chemicals and chemical products (code 20-fixed capital between 10-50 VND billion and between 200-500 VND billion), electrical equipment (code 27-fixed capital between 10-500 VND billion), not-yet-classified machinery and equipment (code 28-fixed capital between 50-200 VND billion), motor vehicles, trailers and semi-trailers (code 
29-fixed capital up to 200 VND billion), and other transport equipment (code 30-fixed capital between 200-500 VND billion) are also observed with significantly positive effects. Besides, two high-tech manufacturing sectors, namely pharmaceuticals and medicinal chemicals (code 21-fixed capital between 10-50 VND billion), and computer, electronic and optical products (code 26-fixed capital between 200-500 VND billion) indicate the existence of significantly positive effects.

With regards to firms' capital-to-labor ratio, Table 6 shows that the firms' capital intensity is statistically significantly positive in food products (code 10-fixed capital larger than 500 VND billion), textiles (code 13-fixed capital larger than 500 VND billion), and wearing apparel (code 14-fixed capital between 50-200 VND billion and larger than 500 VND billion). Others include leather and related products (code 15-fixed capital larger than 500 VND billion), paper and paper products (code 17-fixed capital between 50-200 VND billion and larger than 500 VND billion), and fabricated metal products (code 25-fixed capital between 50-200 VND billion and larger than 500 VND billion). Moreover, two medium low-tech manufacturing sectors, including rubber and plastics products (code 22-fixed capital larger than 500 VND billion) and other non-metallic mineral products (code 23-fixed capital between 50-200 VND billion and for larger than 500 VND billion), show significantly positive effects. Besides, two high-tech manufacturing sectors, namely pharmaceuticals and medicinal chemicals (code 21-fixed capital between 50-200 VND billion) and computer, electronic and optical products (code 26-fixed capital between 200-500 VND billion) show significantly positive impacts. Last but not least, one medium high-tech manufacturing sector, namely other transport equipment (code 30-fixed capital between 200-500 VND billion) also shows a significantly positive impact. However, the statistically negative effect of the firms' capital intensity is observed in low-tech manufacturing sectors, such as textiles (code 13-fixed capital less than 10 VND billion) and rubber and plastics products (code 22-fixed capital up to 50 VND billion); and in the medium low-tech manufacturing sectors, such as other non-metallic mineral products (code 23-fixed capital between 10-50 VND billion). The list includes the medium high-tech manufacturing sectors, namely not-yet-classified machinery and equipment (code 28-fixed capital in the range 50-200 VND billion) and motor vehicles, trailers and semi-trailers (code 29-fixed capital in the range 50-200 VND billion). Productivity heterogeneity in the capital has also been discovered in Kim (2018), who found that higher capital intensity is associated with lower productivity in the medium-low-technology and high-technology manufacturing sectors in Japan.

The level of real value-added per worker of firms is shown to be positively correlated with TFP only in wearing apparel (code 14-fixed capital between 50-500 VND billion) and fabricated metal products (code 25-fixed capital between 10-50 VND billion), and in two medium high-tech manufacturing sectors, including chemicals and chemical products (code 20-fixed capital between 50-200 VND billion), and other transport equipment (code 30-fixed capital between 10-50 VND billion). However, a statistically negative effect of the firms' capital intensity is observed in pharmaceuticals and medicinal chemicals (code 21—fixed capital between 50-200 VND billion).

\section{Conclusions and Implications}

Several challenges remain for researchers to understand differences in total factor productivity, namely: (1) empirical difficulties in the measurement of TFP levels; (2) model uncertainty on key determinants; and (3) heterogeneity between manufacturing sectors and heterogeneity within manufacturing sectors in terms of labor and capital that have been increasing reconsidered recently. This paper, using Vietnamese firm-level data for the period 2010-2015, applied the method of Ackerberg et al. (2006), which is an extension of the technique by Levinsohn and Petrin (2003), which has been employed to measure TFP, and the generalized method of moments, which has been used to identify factors that affect differences in the level of productivity across manufacturing subsectors and clarify the heterogeneous determinants of TFP within sectors. To the best of our knowledge, this study is the first to examine the heterogeneity of determinants of firm-level TFP in Vietnam and in a transitional country as well using GMM technique. The current paper is also 
the first attempt to explore the issue of economic growth in terms of manufacturing sectors within a specific country. Our estimations, in general, show that large firms have significantly greater TFP levels than small firms in some fragmentations of firms in terms of both labor and total capital and in some manufacturing sectors. To be more specific:

First, regarding labor heterogeneity, our estimations show that large firms in terms of labor have significantly greater TFP levels than small firms in some fragmentations of a firm's labor size and in some manufacturing sectors, as indicated in previous studies. However, the results also confirm the recent finding that a statistically negative effect of a firm's size exists. The studies also found that labor quality has a positive effect on the productivity in some manufacturing sectors. In addition, our study may be the first in discovering that the negative effect of labor quality exists in certain low-tech manufacturing sectors and at certain levels of labor, namely: leather and related products (code 15) and paper and paper products (code 17), both with workers in the range of 300-500 workers. Regarding the firms' ages, the results also confirm both the vintage effects and the learning-by-doing effects existing in certain manufacturing sectors, and that contributes to the mixture pictures of empirical studies so far. As for the firms' productivity adjustment, the significant positive effects of lagged total factor productivity confirm a relatively quick adjustment over time in certain sectors, as found in some previous studies. Last but not least, our results found both significantly positive and significantly negative effects of firms' capital intensity level (measured by capital-to-labor ratio) in certain sectors and a purely negative effect of labor productivity in the low-tech manufacturing and medium high-tech manufacturing sectors.

Second, with respect to capital heterogeneity, our results may be the first to find that many sources of TFP are so dependent on the heterogeneity of firms' total capital size. Specifically, our estimations show that large firms in terms of labor have significantly greater TFP levels than small firms in some fragmentations of a firms' capital size and in some manufacturing sectors. Similarly, we found significantly negative effects of labor quality, mixture effects of firms' ages, positively quick adjustments in productivity over time, mixture effects of firms' capital intensity, and positive effects of labor productivity in some low-tech manufacturing and medium high-tech manufacturing sectors, as well as the negative effect in the high-tech manufacturing sector, namely pharmaceuticals and medicinal chemicals (code 21).

Our results lead to some direct policy implications. Specifically, they point out that to explore firm productivity from the resource-based view, we need to master the heterogeneous firms' behavior. In other words, it is suggested that the government should build and improve relevant policies that are tailored within the Vietnamese firm characteristics so as to help them strengthen their operations and enhance productivity. Secondly, appropriate industrial policies to enhance TFP in each industry can be established so as to effectively maintain the sustainable industrialization of the country.

Despite our important findings toward firm productivity, the study still faces some limitations. That is, our analysis focused on the main internal determinants of TFP due to the insufficient sources of data, while external factors such as economic shocks and macroeconomic conditions can play important roles. Including external factors can induce more fruitful policy implications. Second, several internal factors, such as managerial and governance aspects, were not considered due to data limitations. Third, the limitation of the paper also comes from the interpretation of wage in terms of labor quality, since wages have many facets by themselves. Those issues will guide further research in the future.

Supplementary Materials: The following are available online at http://www.mdpi.com/2227-7099/8/3/57/s1: Table S1: Summary statistics for determinants of TFP in Vietnamese manufacturing firms. Table S2: Labor-heterogeneity determinants of TFP by industries, 2010-2015. Table S3: Capital-heterogeneity determinants of TFP by industries, 2010-2015.

Author Contributions: Q.-T.N. designed the overall research, collected the dataset, and conducted the empirical analysis. Q.-T.N. was the main writer of the paper. Q.-V.T., T.-D.N., and T.-T.N. contributed to the review and editing of the paper and to the statistical analysis. All authors have read and agreed to the published version of the manuscript. 
Funding: This research is funded by the Vietnam National University—Ho Chi Minh City, Vietnam, under grant number C2018-34-05.

Acknowledgments: The authors are grateful to the two anonymous reviewers and the Academic Reviewer whose comments have contributed to improving the quality of this paper.

Conflicts of Interest: The authors declare no conflict of interest.

\section{References}

Ackerberg, Dan, Kevin Caves, and Garth Frazer. 2006. Structural Estimation of Production Functions. Los Angeles: Department of Economics, UCLA.

Aghion, Philippe, and Peter Howitt. 2006. Appropriate growth policy: A unifying framework. Journal of the European Economic Association 4: 269-314. [CrossRef]

Ali, Merima, and Jack Peerlings. 2011. Value added of cluster membership for micro enterprises of the handloom sector in Ethiopia. World Development 39: 363-74. [CrossRef]

Arellano, Manuel, and Stephen Bond. 1991. Some tests of specification for panel data: Monte Carlo evidence and an application to employment equations. The Review of Economic Studies 58: 277-97. [CrossRef]

Aw, Bee Yan, Mark J. Roberts, and Daniel Yi Xu. 2008. R\&D investments, exporting, and the evolution of firm productivity. American Economic Review 98: 451-56.

Barney, Jay B. 2000. Firm resources and sustained competitive advantage. In Economics Meets Sociology in Strategic Management. Bingley: Emerald Group Publishing Limited, pp. 203-27.

Barney, Jay B. 2001. Is the resource-based "view" a useful perspective for strategic management research? Yes. Academy of Management Review 26: 41-56.

Bartel, Ann, Casey Ichniowski, and Kathryn Shaw. 2007. How does information technology affect productivity? Plant-level comparisons of product innovation, process improvement, and worker skills. The Quarterly Journal of Economics 122: 1721-58. [CrossRef]

Bartelsman, Eric, John Haltiwanger, and Stefano Scarpetta. 2009. Cross-Country Differences in Productivity: The Role of Allocation and Selection. Discussion Paper No. 4578. Bonn: IZA Institute of Labor Economics.

Bernard, Andrew B., and J. Bradford Jensen. 1999. Exporting and Productivity. No. w7135. Cambridge: National Bureau of Economic Research.

Bernard, Andrew B., Stephen J. Redding, and Peter K. Schott. 2010. Multiple-product firms and product switching. American Economic Review 100: 70-97. [CrossRef]

Bloom, Nicholas, and John Van Reenen. 2007. Measuring and explaining management practices across firms and countries. The Quarterly Journal of Economics 122: 1351-408. [CrossRef]

Bloom, Nicholas, and John Van Reenen. 2010. Why do management practices differ across firms and countries? Journal of Economic Perspectives 24: 203-24. [CrossRef]

Blundell, Richard, and Stephen Bond. 1998. Initial conditions and moment restrictions in dynamic panel data models. Journal of Econometrics 87: 115-43. [CrossRef]

Botrić, Valerija, Ljiljana Božić, and Tanja Broz. 2017. Explaining firm-level total factor productivity in post-transition: Manufacturing vs. services sector. Journal of International Studies 10: 77-90. [CrossRef] [PubMed]

Bridgman, Benjamin, Shi Qi, and James Andrew Schmitz. 2009. The Economic Performance of Cartels: Evidence from the New Deal US Sugar Manufacturing Cartel, 1934-74. Minneapolis: Federal Reserve Bank of Minneapolis, vol. 437.

Brock, William A., and Steven N. Durlauf. 2001. What have we learned from a decade of empirical research on growth? Growth empirics and reality. The World Bank Economic Review 15: 229-72. [CrossRef]

Brown, J. David, John S. Earle, and Almos Telegdy. 2006. The productivity effects of privatization: Longitudinal estimates from Hungary, Romania, Russia, and Ukraine. Journal of Political Economy 114: 61-99. [CrossRef]

Cao, Lizhan, Zhongying Qi, and Junxia Ren. 2017. China's industrial total-factor energy productivity growth at sub-industry level: A two-step stochastic metafrontier Malmquist index approach. Sustainability 9: 1384. [CrossRef]

Castellacci, Fulvio. 2007. Technological regimes and sectoral differences in productivity growth. Industrial and Corporate Change 16: 1105-45. [CrossRef]

Castellani, Davide, and Giorgia Giovannetti. 2010. Productivity and the international firm: Dissecting heterogeneity. Journal of Economic Policy Reform 13: 25-42. [CrossRef] 
Castellani, Davide, Francesco Serti, and Chiara Tomasi. 2010. Firms in international trade: Importers' and exporters' heterogeneity in Italian manufacturing industry. World Economy 33: 424-57. [CrossRef]

Clerides, Sofronis K., Saul Lach, and James R. Tybout. 1998. Is learning by exporting important? Micro-dynamic evidence from Colombia, Mexico, and Morocco. The Quarterly Journal of Economics 113: 903-47. [CrossRef]

Constantini, James A., and Marc J. Melitz. 2008. The dynamics of firm-level adjustment to trade liberalization. In The Organization of Firms in a Global Economy. Edited by E. Helpman, D. Marin and T. Verdier. Cambridge: Harvard University Press.

Dhawan, Rajeev. 2001. Firm size and productivity differential: Theory and evidence from a panel of US firms. Journal of Economic Behavior E Organization 44: 269-93.

Evans, Paul. 1998. Using panel data to evaluate growth theories. International Economic Review 39: 295-306. [CrossRef]

Fabrizio, Kira R., Nancy L. Rose, and Catherine D. Wolfram. 2007. Do markets reduce costs? Assessing the impact of regulatory restructuring on US electric generation efficiency. American Economic Review 97: 1250-77. [CrossRef]

Fernandes, Ana M. 2008. Firm Productivity in Bangladesh Manufacturing Industries. World Development 36: 1725-44. [CrossRef]

Forbes, Silke J., and Mara Lederman. 2010. Does vertical integration affect firm performance? Evidence from the airline industry. The Rand Journal of Economics 41: 765-90. [CrossRef]

Foster, Lucia, John Haltiwanger, and Chad Syverson. 2008. Reallocation, firm turnover, and efficiency: Selection on productivity or profitability? American Economic Review 98: 394-425. [CrossRef]

Giang, Mai Huong, Tran Dang Xuan, Bui Huy Trung, Mai Thanh Que, and Yuichiro Yoshida. 2018. Impact of investment climate on total factor productivity of manufacturing firms in Vietnam. Sustainability 10: 4815. [CrossRef]

Giang, Mai Huong, Bui Huy Trung, Yuichiro Yoshida, Tran Dang Xuan, and Mai Thanh Que. 2019. The Causal Effect of Access to Finance on Productivity of Small and Medium Enterprises in Vietnam. Sustainability 11: 5451. [CrossRef]

Goedhuys, Micheline. 2007. Learning, product innovation, and firm heterogeneity in developing countries; Evidence from Tanzania. Industrial and Corporate Change 16: 269-92. [CrossRef]

Harper, Michael J. 2007. Technology and the theory of vintage aggregation. In Hard-to-Measure Goods and Services: Essays in Honor of Zvi Griliches. Chicago: University of Chicago Press, pp. 99-120.

Harris, Richard, and John Moffat. 2015. Plant-level determinants of total factor productivity in Great Britain, 1997-2008. Journal of Productivity Analysis 44: 1-20. [CrossRef]

Harris, Richard I.D., and Stephen Drinkwater. 2000. UK plant and machinery capital stocks and plant closures. Oxford Bulletin of Economics and Statistics 62: 243-43. [CrossRef]

Head, Keith, and John Ries. 2003. Heterogeneity and the FDI versus export decision of Japanese manufacturers. Journal of the Japanese and International Economies 17: 448-67. [CrossRef]

Hsieh, Chang-Tai, and Peter J. Klenow. 2009. Misallocation and manufacturing TFP in China and India. The Quarterly Journal of Economics 124: 1403-48. [CrossRef]

Hulten, Charles R., and Frank C. Wykoff. 1980. The Measurement of Economic Depreciation. Washington: Urban Institute.

Hulten, Charles R. 1992. Growth Accounting When Technical Change Is Embodied in Capital. No. w3971. Cambridge: National Bureau of Economic Research.

Ilmakunnas, Pekka, Mika Maliranta, and Jari Vainiomäki. 2004. The roles of employer and employee characteristics for plant productivity. Journal of Productivity Analysis 21: 249-76. [CrossRef]

İmrohoroğlu, Ayşe, and Şelale Tüzel. 2014. Firm-level productivity, risk, and return. Management Science 60: 2073-90. [CrossRef]

Isaksson, Anders. 2007. Determinants of Total Factor Productivity: A Literature Review. Woking Paper. Vienna: Research and Statistics Branch, UNIDO.

Jorgenson, Dale W., Mun S. Ho, and Kevin J. Stiroh. 2005. Productivity, Volume 3: Information technology and the American growth Resurgence. Cambridge: MIT Press, Books 3.

Jorgenson, Dale W., Mun S. Ho, and Kevin J. Stiroh. 2008. A retrospective look at the US productivity growth resurgence. Journal of Economic Perspectives 22: 3-24. [CrossRef] 
Jovanovic, Boyan. 1982. Selection and the Evolution of Industry. Econometrica: Journal of the Econometric Society 50: 649-70. [CrossRef]

Jovanovic, Boyan, and Y. Nyarko. 1994. Learning by Doing and the Choice of Technology. Cambridge: National Bureau of Economic Research.

Jovanovic, Boyan, and Y. Nyarko. 1996. Learning by doing and the choice of technology. Econometrica 64: 1299-310. [CrossRef]

Jung, Moosup, and Keun Lee. 2010. Sectoral systems of innovation and productivity catch-up: Determinants of the productivity gap between Korean and Japanese firms. Industrial and Corporate Change 19: 1037-69. [CrossRef]

Kendrick, John W. 1961. Productivity Trends in the United States. Princeton: Princeton University Press.

Kim, Sangho. 2018. Firm heterogeneity in sources of total factor productivity growth for Japanese manufacturing firms. Applied Economics 50: 6301-15. [CrossRef]

Kim, Soo-Il, Munisamy Gopinath, and Hanho Kim. 2009. High productivity before or after exports? An empirical analysis of Korean manufacturing firms. Journal of Asian Economics 20: 410-18. [CrossRef]

Kreuser, Carl Friedrich, and Carol Newman. 2018. Total factor productivity in South African manufacturing firms. South African Journal of Economics 86: 40-78. [CrossRef]

Lee, Frank C, and Jianmin Tang. 2001. Multifactor productivity disparity between Canadian and US manufacturing firms. Journal of Productivity Analysis 15: 115-28.

Levinsohn, James, and Amil Petrin. 2003. Estimating production functions using inputs to control for unobservables. The Review of Economic Studies 70: 317-41. [CrossRef]

Lu, Jiangyong, Yi Lu, Yi Sun, and Zhigang Tao. 2017. Intermediaries, firm heterogeneity and exporting behaviour. The World Economy 40: 1381-404. [CrossRef]

Maksimovic, Vojislav, and Gordon Phillips. 2001. The market for corporate assets: Who engages in mergers and asset sales and are there efficiency gains? The Journal of Finance 56: 2019-65. [CrossRef]

Malerba, Franco. 1992. Learning by firms and incremental technical change. The Economic Journal 102: 845-59. [CrossRef]

Martin, Philippe, Thierry Mayer, and Florian Mayneris. 2011. Spatial concentration and plant-level productivity in France. Journal of Urban Economics 69: 182-95. [CrossRef]

Melitz, Marc J. 2003. The impact of trade on intra-industry reallocations and aggregate industry productivity. Econometrica 71: 1695-725. [CrossRef]

Mohnen, Pierre, and Bronwyn H Hall. 2013. Innovation and productivity: An update. Eurasian Business Review 3: $47-65$.

Newman, Carol, John Rand, Theodore Talbot, and Finn Tarp. 2015. Technology transfers, foreign investment and productivity spillovers. European Economic Review 76: 168-87. [CrossRef]

Ngo, Quang Thanh, and Canh Thi Nguyen. 2019. Do export transitions differently affect firm productivity? Evidence across Vietnamese manufacturing sectorss. Post-Communist Economies, 1-27. [CrossRef]

Ngo, Quang Thanh, and Quang Van Tran. 2020. Firm heterogeneity and total factor productivity: New panel-data evidence from Vietnamese manufacturing firms. Management Science Letters 10: 1505-12. [CrossRef]

Nichter, Simeon, and Lara Goldmark. 2009. Small firm growth in developing countries. World Development 37: 1453-64. [CrossRef]

Oliner, Stephen D., Daniel E. Sichel, and Kevin J. Stiroh. 2007. Explaining a productive decade. Brookings Papers on Economic Activity 2007: 81-137. [CrossRef]

Pakes, Ariel, and Richard Ericson. 1998. Empirical implications of alternative models of firm dynamics. Journal of Economic Theory 79: 1-45. [CrossRef]

Penrose, Edith Tilton. 1959. The Theory of the Growth of the Firm. New York: Oxford University Press.

Roodman, David. 2009. How to do xtabond2: An introduction to difference and system GMM in Stata. The Stata Journal 9: 86-136. [CrossRef]

Söderbom, Måns, and Francis Teal. 2004. Size and efficiency in African manufacturing firms: Evidence from firm-level panel data. Journal of Development Economics 73: 369-94. [CrossRef]

Sakellaris, Plutarchos, and Daniel J. Wilson. 2004. Quantifying embodied technological change. Review of Economic Dynamics 7: 1-26. [CrossRef] 
Satpathy, Lopamudra D, Bani Chatterjee, and Jitendra Mahakud. 2017. Firm Characteristics and Total Factor Productivity: Evidence from Indian Manufacturing Firms. Margin: The Journal of Applied Economic Research 11: 77-98. [CrossRef]

Syverson, Chad. 2011. What determines productivity? Journal of Economic Literature 49: 326-65. [CrossRef]

Thornton, Rebecca Achee, and Peter Thompson. 2001. Learning from experience and learning from others: An exploration of learning and spillovers in wartime shipbuilding. American Economic Review 91: 1350-68. [CrossRef]

Tornatzky, L., and Mitchell Fleischer. 1990. The Process of Technology Innovation. Lexington: Lexington Books, p. 165.

Tran, Viet T., Trung Thanh Nguyen, and Nguyet T. M. Tran. 2019. Gender difference in access to local finance and firm performance: Evidence from a panel survey in Vietnam. Economic Analysis and Policy 63: 150-64. [CrossRef]

United Nations Statistical Division. 2008. International Standard Industrial Classification of All Economic Activities (ISIC). New York: United Nations Publications.

Van Biesebroeck, Johannes. 2003. Productivity dynamics with technology choice: An application to automobile assembly. The Review of Economic Studies 70: 167-98. [CrossRef]

Van Biesebroeck, Johannes. 2005. Firm size matters: Growth and productivity growth in African manufacturing. Economic Development and Cultural Change 53: 545-83. [CrossRef]

Venturini, Francesco. 2015. The modern drivers of productivity. Research Policy 44: 357-69. [CrossRef]

Wernerfelt, Birger. 1984. A resource-based view of the firm. Strategic Management Journal 5: 171-80. [CrossRef]

Williamson, Oliver E. 1967. Hierarchical control and optimum firm size. Journal of Political Economy 75: 123-38. [CrossRef]

Xu, Chang, Jianbing Guo, Baodong Cheng, and Yu Liu. 2019. Exports, Misallocation, and Total Factor Productivity of Furniture Enterprises. Sustainability 11: 4892. [CrossRef]

(C) 2020 by the authors. Licensee MDPI, Basel, Switzerland. This article is an open access article distributed under the terms and conditions of the Creative Commons Attribution (CC BY) license (http://creativecommons.org/licenses/by/4.0/). 